\title{
Code Switching and Code Mixing in the Arabic Learning of Egypt Sandwich Program 2019
}

DOI:10.22515/ljbs.v6i2.3004

\author{
JAMALUDDIN ABDUL AZIZ \\ jamaluddinabdulaziz7@gmail.com \\ MOHAMAD ZAKA AL FARISI \\ zaka@upi.edu \\ Universitas Pendidikan Indonesia \\ Bandung, Indonesia \\ MUHAMMAD ZAINAL MUTTAQIEN \\ English Letters Study Program, IAIN Surakarta \\ Surakarta, Indonesia
}

submitted: 20/11/2021 revised: 21/12/2021 accepted: 22/12/2021 published: 27/12/2021 pages: 167-179

ABSTRACT This study discusses the types of code switching and code mixing occured in the utterances of Egypt Sandwich Program 2019instructors. It also explores the factors that cause the two language phenomena and their effects toward non-Arabic speakers. In research design, participatory observational study was applied in which the researchers participated in the Arabic language learning activities in the program. The results showed that both internal and external code switching occurred in the speech of the instructors. Meanwhile, for code mixing, intersentential and intrasentential process were found in this study. The code switching and code mixing found in this study only occured among Arabic fusha, Arabic 'amiyah, and English. In general, the main factor that drove the speakers to perform code switching and code mixing in the program was the speaker's habitl. Misunderstandings sometimes happened between the instructors and the students due to the emergence of code switching and code mixing in the event.

Keywords: code switching, code mixing, Arabic learning, Egypt Sandwich Program

INTRODUCTION Code switching and code mixing are two phenomena that commonly occur in a multilingual society. According to Rokhman (in Gayatri et al. 2016), in a multilingual society, it is impossible to use one language only without considering another language or its elements since there is interdependency between one and the other. It indicates that every language has its own weaknesses so that it is necessary for one languages to complete the other.

Both code switching and code mixing are frequently found in the proces of learning languages, including Arabic. They are are sometimes practiced by the teacher, as a speaker, to make the students able to understand the learning materials more easily. However, these two language phenomena often lead to communication difficulties since the code used is not the one that is understood by the speech partners.

Code is a term referring to a language with its variation. In the Arabic learning of Egypt Sandwich Program 2019, the basic code used by the speaker as, of course, fusha Arabic or formal Arabic. However, in some occasions, there were found some speakers who performed code switching and code mixing to 'amiyah or daily Arabic, which consequently could lead to misunderstandings. Some examples of vocabulary used from the second عariety are عايز (want), كويس (why), dan (good). In addition, the phenomena of code switching and code mixing sometimes involved English since it is considered to be more acceptable than Arabic.

These phenomena of code switching and code mixing in the Arabic learning process at Egypt Sandwich Program 2019 was interesting to study 
and the researchers decided to take the instructors who spoke in 'amiyah Arabic as the object of the study or samples of this research.

LITERARY Ohoiwutun (in Herdiana \& Sopian 2019, 166) defines code switching is a turn REVIEW in using language from one language or dialect to another. It is divided into

Theoretical Background two, that is internal and external code switching. Internal code switching occurs between local languages within a national language, between dialects in a local language or between varieties and styles in a dialect (Indriyani 2019, 693). One example is when a speaker switches the code from Indonesian, as a national language, to Sundanese that is a local language. Meanwhile, external code switching occurs between domestic and foreign languages (Indriyani 2019, 693), for example, when a speaker turn the code from Indonesian to English.

Naturally, the discussion on code switching cannot be separated from its pair, code mixing. Rohmah et al. $(2019,21)$ state that code mixing is a phenomenon of the existence of pieces from another language within the utterances spoken in a language. Code mixing can further be divided into three types according to the inserted elements that cause the phenomenon, namely inner, outer, and hybrid code-mixing (Hastuti 2020, 3).

According to Jendra (in Agustina 2020, 118), inner or internal code-mixing utilizes the elements of other languages from the same family, such when an Indonesian speaker inserts Javanese elements in his/her speech. Meanwhile, outer or external code-mixing occurs when the elements inserted coming from foreign language, for example, when the Indonesian speaker insert the elements from English language to his/her speech. On the other hand, as stated by Meldani $(2018,7)$, hybrid code-mixing is a combination between local and foreign language use in addition to the main language. The language units inserted in a code mixing process can be divided into four categories, namely words, phrases, clauses, and baster. (Laiman et al. 2018, 49$50)$.

Previous From the tracing, there has not been found any study with the topic exactly Studies similar to this current research. However, there are some research results which have, at least, one aspect similar to this research's. One of them is the study conducted by Tohe (2005) with the title Fusha and 'Amiyah Arabic along with Their Problems. This research discusses the similarities ad differences between fusha and 'amiyah Arabic in general. Another study was conducted by Astuti (2017) with the title The Diglossia in a Speech Community on Arabic Language Use. This research is focused on two varieties of Arabic that can live together within a language society. Meanwhile, in his research entitled Code Switching and Code Mixing in the Teaching Process of Indonesian Language, Sudarja (2019) investigates both code switching and code mixing occurred from Indonesian to English.

This current research was focused on identifying code switching and code mixing occurred in the Arabic learning at Egypt Sandwich Program 2019 that involve the instructors as the speakers and Indonesian students as the speech partners. In addition, this research was also purposed to identify those two linguistic phenomena based their categories. Lastly, there would be a description of some factors influencing the cases and the impacts to the speech partners. 
RESEARCH The method applied in this research was qualitative-descriptive because the

METHOD data collected, analyzed, and displayed were in the forms of words, phrases, or clauses and not numbers. This research was designed as participatory observations in which researchers positioned themselves as the participants in the Arabic learning investigated.

As it was qualitative research, the researchers played role as the main instrument who conducted research planning, data collection and analyses, conclusion drawing, as well as result reporting. The sampling techniques applied were non-probability and purposive sampling. It is because not all of the members of population were involved as the data sources and the instructors taken as the data sources were selected based on certain criteria. Therefore, the data employed for this research were speech acts performed by the instructors of Egypt Sandwich Program 2019. The other data were in the form of the results of interviews with the head and some office staff of the educational institution hosting the program, Ma'had Mu'allimil Qur'an. These supporting data were needed as the complement of the main data, that is code switching and code mixing performed by the instructors.

For collecting the data of this research, three different techniques were applied, namely participant observation, semi-structured interview, and document analysis. After the data were completed, the researchers then analyze the data for drawing the conclusion. The process of analyzing the data included: (1) listening to the record, (2) transcribing the speech into written form and checking the correctness, (3) reducing the data or separating the speech which did not contain code switching and code mixing out from the actual data, (4) classifying the data based on the categories of code switching and code mixing along with the causing factors and the impacts to the speech partners, and (4) drawing the conclusion of the phenomena being observed.

Table 1: The Occurrences of Code Switching

\begin{tabular}{clc}
\hline Type & \multicolumn{1}{c}{ Causing Factor } & Freq. \\
\hline \multirow{2}{*}{ Internal } & Speaker's habit & 9 \\
& The appearance of the third party & 3 \\
& Soften request or command & 1 \\
External & Speaker's motif on prestige & 2 \\
& Intention to explain and interpret & 1 \\
\hline
\end{tabular}

Table 2: The Occurrences of Code Mixing

\begin{tabular}{clc}
\hline Type & \multicolumn{1}{c}{ Causing Factor } & Freq. \\
\hline Internal & Speaker's habit & 13 \\
& The appearance of the third party & 1 \\
External & Lexical needs & 2 \\
& Speaker's motif of prestige & 2 \\
& Intention to build intimacy & 2 \\
& Intention to explain and interpret & 1 \\
& Intention to reduce the risk of & \\
& making mistakes in delivering & 1 \\
& messages & \\
\hline
\end{tabular}


CODE SWITCHING AND CODE MIXING

DISTRIBUTION

TYPES OF CODE

SWITCHING AND CODE MIXING

Internal Code

Switching
Based on research findings, there were found 16 code switching and 22 code mixing occurences performed by the speakers. The data display of the former can be seen in Table 1, whereas for the latter, it can be observed in Table 2 .

From both tables, it can be concluded that the most dominant factor causing code switching and code mixing is the speaker's habit. In other words, the speakers commonly insert the elements of other languages in their daily communication as what is stated by Hapsari $(2020,49)$.

Datum (1) shows the speech events in which the speaker performs internal code switching from fusha to amiyah Arabic. This process of code switching can be divided into two stages.

Datum (1)

Stage A

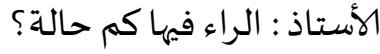

$$
\begin{aligned}
& \text { الطلاب : ثلاثة - ماثة } \\
& \text { الأستاذ : تُرقق تُفخمر يجوز فيها التفخيم والترقيق } \\
& \text { أول حالة ترقق في ستة أحوال.ألناهمفي المرة الماضية أ لناهم مكسورة, ساكنة بعد } \\
& \text { مكسور وبعدها حرف استفال, مكسورة كسرة عارضاة, ساكنة بعد ياء مدية أو لينة, }
\end{aligned}
$$

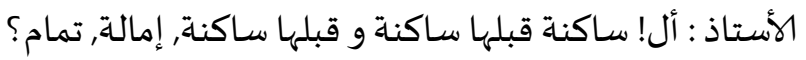

Stage B

$$
\begin{aligned}
& \text { إسراء : حضرة, تشرب ايه؟ } \\
& \text { الأستاذ : مفش يانسون؟ : حضرة تشئ آهرب } \\
& \text { إسراء : فيه يانسون } \\
& \text { الأستاذ : معنا الواحد : فيه يالدون } \\
& \text { إسراء : : طيب تمام }
\end{aligned}
$$

Isro : Ustaz, What do you want to drink?

Instructor : Isn't there any sweet tea?

Isro : It's available.

Instructor : Together with us, one.

Isro : Alright. I'm ready.

In the first stage, the instructor as the speaker uses fusha Arabic for explaining the learning material to the students. A teacher has to explain the materials using the appropriate language, that is the language variety for academic purpose (Chairina 2019, 2). For Arabic learning, it must be fusha 
Arabic. However, in the second stage there is office staff, named Isro, who knocked the door and entered the class to ask what kind of drink preferred by the instructor in 'amiyah Arabic. Thus, it can be concluded that in the speech event happens external code switching from fusha to 'amiyah Arabic. According to Kurniasih \& Zuhriyah $(2017,54)$, code switching happens when the speaker changes the language he/she speaks deliberately. In his speech, the instructor pronounces the word مفي + شيs as the acronym of the words + $L$ that mean 'not be there' (Mufrodi 2015, 212).

According to Saville-Troike (in Kalangit 2016, 6) the factors that encourage a speaker to perform code switching among others are for: (1) softening or streghthening a request or command; (2) lexical needs; (3) excluding others when the conversation is addressed to a certain speech partner. Particularly for internal code switching, the dominant driving factor is the presence of the third party by whom the speaker excludes the other persons since the messages are only addressed to him/her. Basically, the purpose of code switching is to suit to the speech partner, topic, domain, and social distance in a speech event (Liyana 2017, 146).

Not only internal code switching, actually, the instructor performs internal code mixing either. This emerges in the form of word insertion when the speaker used the word ألناه into his utterances in fusha Arabic. The sound of letter is rarely heard amid Egyptian people (Pancarani et al. 2016, 208). In the case, uvular sound changes into glottal stop (Mufrodi 2015, 195). The change is caused by the adjacent consonant articulation sounds and the lighter sound pronounced by Egyptian people (Fadhilah et al. 2020, 57).

In the speech act shown Datum (2), the speaker perform internal code switching from fushā to 'amiyah Arabic. The process of code switching in the conversation can also be divided into two stages.

Datum (2)

Stage A

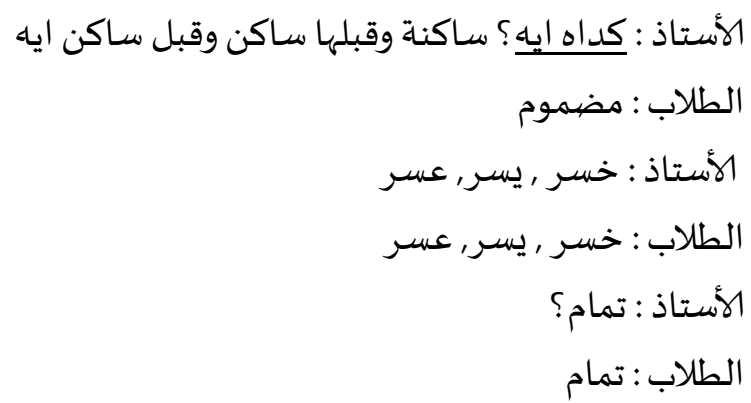

Instructor : What is that one (categorized into)? Letter $\lrcorner$ with sukun harakat. Before it a sukun and before the sukun, what is this?

Student : Letter with damah harakat.

Instructor : Read it in tarqiq, tafkhim, and can be read in tarqiq ortafkhim.

Instructor : (drawback, easiness, difficulty)

Student : (drawback, easiness, difficulty)

Instructor : Clear?

Student : Yes. It's clear.

Stage B

الأستاذ : انتو فاهمين و لا لاء لو مش فاهمين قولوعشان اشرح تانتي ماشي؟

Instructor : Do you understand me/my (explanation) or not? If you haven't understood, tell me. I will repeat it once more. OK? 
In the first stage, the instructor as the speaker uses 'amiyah Arabic when he gives a question to the student, that is كداه ايه؟ . In 'amiyah Arabic, consonant $\dot{j}$, which is categorized into voiced-fricative-interdental consonant, is pronounced into 2 , which is categorized into voiced-plosive-apicodental consonant (Mufrodi 2015, 200). Meanwhile, the word ايه is the acronym of the words ماذا أي + شيء + ماذ which is equivalent to the word fusha Arabic (Mufrodi 2015, 213).

After the student answer his question, the speaker gives an example of the pronunciation of letter $\boldsymbol{s}$ in a verse of al-Qur'an which is read in tafkhim. The speaker who is an Egyptian person will not pronounce holy verses of al-Qur'an by mixing them with 'amiyah Arabic dialect. It is in line with what has been stated by Ibn al-Jazari:

$$
\begin{aligned}
& \text { والأخذ بالتجويد حتم لازم } \\
& \text { من لم يصحح القرآن آثم } \\
& \text { لأنها باه الإله أنزلا لهنج القران } \\
& \text { وهكذا مناه إلينا وصلا لإلها لإلها }
\end{aligned}
$$

And reciting al-Qur'an with tajwid is an obigation.

Whoever recites it in the wrong way, (he then) gets a sin.

Because Allah delivered it like that (with tajwid).

And like that al-Qur'an arrived to us.

Then, in the second stage, the instructor uses 'amiyah Arabic in order to ask whether his explanation is understood or not. However, the students as his speech partners do not give the answers toward the question because they do not understand what he said. It is because amiyah Arabic is a variety for daily communication (Astuti 2017, 158). In his utterance, the speaker pronounces the letter $\backsim$ with the sound of letter ت in the word In this case, interdental sound is turned into alveolar (Mufrodi 2015, 195). Generally, the letter is pronounced as of letter $\Xi$, even though some of Egyptians maintain pronouncing it by the sound of $ث$. (Pancarani et al. 2016, 208). Aside fom that, the speaker also pronounces the word عثان which is equivalent with كي in fusha Arabic. The word is the acronym of على + شنان which mean 'not available' (Mufrodi 2015, 212). Egyptian people frequently use the word to replace (Pancarani et al. 2016, 213). Thus, it can be concluded that in the speech event, code switching happens from fusha to 'amiyah Arabic.

Hoffman (in Kalangit 2016) states that the driving factors of the speaker to do code switching among others are intended for (1) expressing certain topic, (2) quoting from others, (3) empasizing something, (4) interjecting (inserting sentence fillers or connectors), (5) repeating for clarification, (6) clarifying the content of conversation to the speech partner, and (7) showing up group's identity. As in the case, the main factor that drives the code switching is the last one, that is the speaker intends to show himself as an Egyptian, even though the speaker has to clarify the meaning of his utterance to his speech partners.

Usually, besides performing code switching, the instructor, as a speaker, sometimes does internal code mixing as well. Code mixing occurs when the speaker uses a language dominantly and, at the same time, inserting some elements from other languages to support his/her speech (Indrayani 2017, 304). In the example, the speaker inserts the word ايه into his fusha Arabic utterance. Therefore, it can be concluded that the code mixing performed is a kind of word insertion and the driving factor is the speaker's habit. 
The following is a speech act in which the speaker performs internal code switching from fusha to amiyah Arabic.

Datum (3)

$$
\begin{aligned}
& \text { الأستاذ : هناك قول يقول أن من يقرأ القرآن يجب عليه الخشوع. يجب على من يقراً }
\end{aligned}
$$

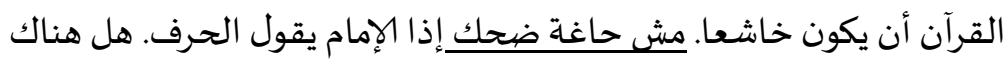

$$
\begin{aligned}
& \text { شيء يضحك؟ }
\end{aligned}
$$

Instructor : There is a statement that one who is reading al- Qur'an has to be serious. It is an obligation for everyone to read al-Qur'an seriously. Don't laugh when the imam (leader of praying) is pronouncing a letter. Is there any thing that makes you laugh?

In the speech event, at the beginning, the instructor as the speaker uses fusha Arabic when he is describing the obligation to do when reading alQur'an. It is because the students laughed with unknown reason. In his speech, the speaker switch the code to 'amiyah Arabic, that is when he pronounces the clause مش حاغة ضحك ماغك In 'amiyah Arabic, The word is made up from the word 1 which is added by the letter $ش$ and followed by the omission of letter 1. The expression replaces the position of letters ليس, ما, لا, غير in fusha Arabic (Pancarani et al. 2016, 207). The word is then followed by حاغة in which letter ج is pronounced by the sound of letter ' $g$ '. It has been common amid Egyptian people (Pancarani et al. 2016, 211).In fusha Arabic, the clause is expressed by that means 'not allowed to laugh'.

Therefore, it can be concluded that in the speech event, it occurs code switching from fusha to'amiyah Arabic. Inversely, the speaker performs code switching in reverse order from amiyah to fusha Arabic as well when he is asking a question that does not need an answer or what is termed as rethoric language style. The purpose of using this language style is to give emphasize, satire or to wake up (Septiani 2020, 21). In addition, another supporting factor of the internal code switching occurrence is due to speaker's habit.

External Code The following is a speech act in which the speaker performs external code Switching switching from fusha Arabic to English.

Datum (4)

$$
\begin{aligned}
& \text { الأستاذ : ما الفرق بين اللغة الحية واللغة الميتة آه ؟! قولوا } \\
& \text { الطلاب : النطق والكلام } \\
& \text { Give me الأستاذ : جدية أكثاب : الكوان } \\
& \text { الطلاب : النطق والكلام }
\end{aligned}
$$

Instructor : Say! What is the difference between living and dead language? What?

Student : Pronunciation and conversation.

Instructor : Give me more seriousness!

Student : Pronunciation and conversation.

In the conversation, the instructor, at the beginning, uses fusha Arabic for giving an instruction to his speech partners. But, subsequently, he mixes'amiyah into fusha Arabic when he is asking a question to them. The code mixing is the use of the word ot that means 'what'. After the speech partner answers the question, the instructor turn his code into English by the sentence 'give me' that is an imperative form for asking something to deliver 
to him. This expression is common for socializing purpose because it is considered modern and intimate (Muharramah 2019, 6). Therefore, in the speech act, code switching happens from fusha Arabic to English because the speaker has a prestige of filling motive, that is he wants to show his intellectuality.

Internal The following is a speech act in which the speaker performs internal code Code Mixing mixing by inserting amiyah to fușhā Arabic.

Datum (5)

$$
\text { هذه الأستاذ : فاء كيف يُنطق ؟ فاء. بالشفة السفلى مع الوصول السنايا العليى. السنايا }
$$

Instructor : Letter fa'. How is it pronounced? Fa'. By meeting the lower lip to the upper front teeth. Front teeth are these, in front of you. Fa'.

In the speech event,the instructor performs internal code mixing when he is explaining the position of front teeth to the students. The case of code mixing is the use of the phrase أمامينت. In fusha Arabic, the phrase must be read separately because it consists of two words, namely أماد that means 'in the front' and أنت that means 'you'. If we refer to the syntax of fusha Arabic, we will find that in order to express the phrase, we cannot use separated pronouns (ضمير منفصل), but we must use connected pronouns (ضمير متصل).

Therefore, the arrangement and the pronunciation of the phrase which follows the principle is أمامك . However, in 'amiyah Arabic, the arrangement and pronunciation applied is أمامأنت where glottal consonant (letter \&) is pronounced in palatal consonant (letter s) or becomes a long vowel (Mufrodi 2015 , 199). Aside from that, from the beginning, 'amiyah language variety is formed without harakat (Pancarani, dkk. 2016, 207). Referring to the case, the speaker pronounces the word أمام by sukun-ing letter ? whose position is at the end of the word. Finally, there meet two sukuns as what is pronounced by the speaker (أمامينت). The purpose is for making the pronounciation easy to do.

Additionally, the speaker uses 'amiyah language dialect as well in his speech with fushalanguage, that is when he is pronouncing letter $ث$ into w in the word السنايا. What is meant by the speaker in his utterance is الثنايا which is the plural form of الثنية that means 'cutting teeth' or what is also called 'front teeth'. In the case, the interdental voice is changed into alveolar (Mufrodi 2015, 195).

Suardi (in Amri 2019, 150) argues that code mixing has certain characteristics that distinguish it from code switching, i.e.: (1) code mixing is not due to the situation or the context of discussion, but depends on the language functions; (2) code mixing occurs due to the speaker's casuality and his/her habit in using langauage; (3) code mixing commonly happens in informal situation; (4) code mixing is only applicable to the language units below clause level. Thus, it can be concluded that code mixing occurs in the form of insertion of words or phrases and the driving factor is the speaker's habit.

The following is a speech event in which the speaker perform internal code mixing by inserting 'amiyah to fusha Arabic. 
Datum (6)

$$
\text { الأستاذ : بينطق من احتكاك الهواء, خارغ من رئتين بالشفة مع الأسنان. فاء }
$$

Instructor : Pronounced from air friction, coming out from the lungs, by the lip and the teeth. Fa'. (the instructor exemplifies the pronounciation of letter $\mathbf{i}$ ).

In the speech act, the instructor performs code mixing when he is describing how to pronounce letter $\omega$ to the student. The code mixing is in the form of the use of verb بينطق . In ammiyah Arabic, there are three forms of present verb. One of them is a verb to which letter $\varphi$ is added. This letter addition at the initial part of a verb indicates that the activity is being done (present continuous) and not going to do (Pancarani et al. 2016, 207). Thus, the verb بينطق means 'being pronounced'. If we refer to fuș hä Arabic syntax, we will find that the letter is categorized into jar letter that is only applicable to nouns. Therefore, it can be concluded that the form of code mixing that occurs is the insertions of words. The factor that causes the internal code mixing is the speaker's preference of a language that identifies him to a certain sociocultural community. Furthermore, the speaker also uses âmiyah language dialect in his utterances of fus hä language as when he is pronouncing letter $ج$ into خاغ in the word $\dot{\varepsilon}$. Palatal voice cannot be found in âmiyah language dialect so that the phoneme is changed into /g/ (Mufrodi 2015, 195). It is because the articulation of $\mathrm{g}$ is considered lighter to be pronounced by Egyptian people (Fadhilah et al. 2020,60)

The folowing is a speech event in which the speaker performs internal code mixing by inserting 'āmiyah to fușhā Arabic.

Datum (7)

$$
\text { الأستاذ : تمام, إذا ليس حجر, لييه؟ ساكنة وقبلها ساكن وقبل ساكن مكسور }
$$

Instructor : Right. So, it is not حجر. Why? (Because of letter $\lrcorner$ ) sukun. Initiated by sukun and there is a letter with kasrah harakat.

(The instructor exemplies the mistake by pronouncing the word in tafkhimm).

In the speech event, the instructor performs internal code mixing when he is explaining a learning material to the students. The code mixing lies in the use of the word ليد_which equals the word لماذا in fusha Arabic. The word is the acronym of the words أي ل + شيء + أ هi that means 'why' (Mufrodi 2015, 213). Aside from that, the speaker also pronounces the word عشان which is equivalent to the word 5 in fusha Arabic. This word is the acronym of the words على + شأن that means 'not be there' (Mufrodi 2015, 212). In any situation, the word لكاذان will always be changed into ليه by byptian people and has likely been a standard formula in 'amiyah Arabic (Pancarani et al. 2016, 214). Thus, the occuring code mixing is in the form of word insertion and the driving factor is the speaker's habit.

Datum (8)

$$
\text { الأستاذ : لبالمرصياد. قل الحروف تُرقق فين؟ }
$$

Instructor : (Seriously watching). Say! Letter $\mathrm{s}$ is read in tarqiq. Where?

In the speech act, the instructor performs internal code mixing when he is asking a question to the students. The code mixing is lies oin the use of phrase فين. In 'amiyah Arabic, the phrase is not pronounced like in fusha. Instead, it is pronounced into fen or fein (Mufrodi 2015, 196). If we refer to the syntax of fusha Arabic, we will find that the expression consists of two words, namely 
and أين. The acronym means 'where' (Mufrodi 2015, 213). In the case, the two words are combined and the letter $s$ is pronounced like letter in'amiyah Arabic.

External Code The following is a speech event in which the speaker performs external code Mixing mixing in the form of English insertion into fusha Arabic.

Datum (9)

$$
\begin{aligned}
& \text { الأستاذ : تتعلمون اللغة الفصحى . And then , أنتم تخطئون في اللغة الفصحى, رغم أن لها } \\
& \text { كتب وتُدرس, وكتب قواعد, تصعبون فيها. واللغة العامية التي ليس لها كتب ولاقو النو }
\end{aligned}
$$

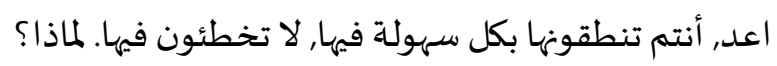

$$
\begin{aligned}
& \text { الطلاب : السماع } \\
& \text { الأستاذ : لأن هذه اللغة تُستعمل. والهستعمال أبو المهارة. }
\end{aligned}
$$

Instructor : You are learning fusha language. And then, you've made a mistake in fusha language. Although this language has books, is taught, (has) books of principles, you find it difficult to study it. And 'amiyah which has no books, principles, you pronounce it easily as a whole inside it. You don't make a mistake in it? Why?

Students : Listening.

Instructor : Because the language is used. Using (language) is the father of skills.

In the speech event, the instructor performs external code mixing by using the words 'and then' which is intended to connect his utterances. Here, the speaker mixes English into fusha Arabic because he suggests that English is more understandable by the students. As a language for global communication, English mastery is not only needed for academic purpose (limited to scientific aspects), but also as a means of global communication (Handayani 2016, 104). Thus, it can be concluded that the form of code mixing occurs in the conversation is insertion of an element in a word form.

Sumarsono (in Mahesa, 2017, 48) states that the factors causing a speaker to perform code mixing, among others, are: (1) choosing the most comfortable language (variety), (2) immediate situation, (3) background of situation or need of filling motive, (4) choosing a language identical or tied to a certain sociocultural community, (5) having prestige of filling motive for showing intellectuallity.

The driving factors of external code switching emergence in those two events is due to the prestige of filling motive intended by the speaker for showing his intellectuality.

The following is a speech event in which the speaker perform external code mixing in the form of inserting English langauge element into fusha Arabic.

Datum (10)

$$
\text { الأستاذ : قدروا أنني سأحضر يوميا, كل يوم, كل يوم, حتى تنطلق, كل يوم, جمال فوزير دكتور داوود. إذا في الأفتى ما يتحدث؟ كل يوم, كل يوم, كل يوم, }
$$

Instructor : Count that I will be present every day. Every day, until you're going home. Every day Jamal Fauzi, except when Doctor Dawud 
is present. Therefore, what (has been) discussed in the past? Every day, every day, every day, explicit in front of you. Understood?

In the speech event, the instructor performs external code mixing by using the word 'explicit' that means 'clearly seen'. The speaker mixes English to fusha Arabic because he supposes that English is more understandable by his students since it is an international language broadly used for daily communication in different countries, such as USA, Singapore, Australia, and Canada (Wardani 2019, 3).

The speaker has an intention to describe and interpret his utterance about his presence in the classroom. It is because there is a student who does not bring a smartphone in the classroom. A smartphone is needed to support the learning process with the instructor. In the meantime, the student do not think that the instructor who will be in the classroom since his presence does not match the schedule. It can be seen that the code switching occurs in the speech is an insertion of a word by which the speaker intends to give explanation and interpretation.

Basically, the students from Indonesia have different educational backgrounds. Some of them have learned Arabic at elementary schools (SD) and some others did it at junior hig schools (SMP), senior high schools (SMA), and universities. There are even students who have not learned Arabic at all. These differences in educational backgrounds may cause various learning problems or difficulties to the students (Setiyawan 2018, 203). In general, all the students in Egypt Sandwich Program 2019 faced the same difficulty, that is they have not been customized to make communication with the native speakers of Arabic. It indicates the notion that a learning activity must be suited to the competence level of the students.

The exposition above stresses that the students might not already understand the instructor speeches in fusha Arabic, not even in amiyah Arabic. Therefore, frequently, the code switching and code mixing performed by the instructor as a speaker raised negative impacts toward the students, that is misunderstandings. Yusnan et al. $(2020,3)$ state that a communcation will occur when the language used by the speaker can be understood by the speech partner, so that the messages conveyed are well received. In case the students understood some utterances spoken in 'amiyah Arabic by the instructor, it is due to the support from the context of conversation as well as the signs given by instructor to the students. Being aware of this situation, some students attempted to learn 'amiyah Arabic in their leisure time. Although they had not fully comprehended the language, at least it could minimize misunderstandings.

Fortunately, besides in Arabic, the speaker performed code switching and code mixing in English as well. It gave advantages to some students since they mastered English better than they did at Arabic. Nevertheless, it also brought disadvantages to others who had not mastered English well and preferred to have explanations of Arabic words or sentences in Arabic language. However, generally, the code switching and code mixing with English elements were more acceptable compared to that of 'amiyah Arabic.

CONCLUSION From the research findings and discussions on the phenomena of code switching and code mixing in Arabic learning, it can be concluded that the types of code switching occuring in the speech events of the teaching-learning 
process are both internal and external code switching. The former happens from fusha to'amiyah Arabic and vice versa whereas the latter occurs from Arabic to English. Meanwhile, the causing factors of the occurences of code switching are the presence of the third party, the speaker's habit, the intention to soften the request/command, the motive of filling prestige, and the willingness to explain and interpret.

In the same way, the types of code mixing occurred in the learning process are internal and external code mixing as well. The former is in the form of an insertion of 'amiyah words or phrases into fusha Arabic, whereas the latter is costituted by the insertion of English words into either fusha or amiyah Arabic. The driving factors of these phenomena are the intention to explain and interpret, lexical needs, fiilling-prestige motive, the intention to build intimacy, the intention to minimize the risk of misinterpretation on the message, the speaker's habit, and the presence of the third party.

In general, the negative effect coming from code switching and code mixing in the learning process is the emergence of misunderstandings between the instructor and the students.

\section{REFERENCES}

Agustina, R. 2020."Analisis Bentuk Alih Kode dan Campur Kode pada Masyarakat Desa Kalimas Tengah Dusun Mawar Kecamatan Sungai Kakap Kabupate nKubu Raya". Prosiding Seminar Nasional STKIP PGRI Bandar Lampung: $113-126$

Amri, Yusni Khairul. 2019. "Alih Kode dan Campur Kode pada Media Sosial". Prosisding Seminar Nasional PBSI II 2019:149-154

Astuti, Widi. 2017. "Diglosia Masyarakat Tutur pada Penggunaan Bahasa Arab (Kajian Kebahasaan terhadap Bahasa Fusha dan Bahasa "Amiyah Dilihat dari Perspektif Sosiolinguistik)". Al-Manar: Jurnal Komunikasi dan Pendidikan Islam 6 (2): 143-161

Chairina, Viona. 2019. Kedudukan Bahasa Inggris sebagai Bahasa Pengantar dalam Dunia Pendidikan (Preprint. DOI: 10.31227/osf.io/xdajg

Fadhilah, Fina Nur, Af'idatul Khadijah, Sri Suriyani, Rika Astari \& M Irfan Faturrahman. 2020. "Perubahan Bunyi Bahasa Arab Fusha ke dalam Dialek Mesir pada Lagu Tamally Ma'ak". 'A Jamiy: Jurnal Bahasa dan Sastra Arab 9 (1): 47-68

Gayatri, Ni Luh Ayu, I Nyoman Sudiana \& Made Sri Indriani. 2016. "Alih Kode dan Campur Kode Guru dalam Pembelajaran Bahasa Indonesia Kelas VII SMP Negeri 4 Kubutambahan". Jurnal Pendidikan Bahasa dan Sastra Indonesia Undiksha 4 (2): 1 11

Handayani, Sri. 2016. "Pentingnya Kemampuan Berbahasa Inggris sebagai dalam Menyongsong Asean Community 2015". Jurnal Profesi Pendidik 3 (1): 102-106

Hapsari, Estuning Dewi. 2020. "Alih Kode dan Campur Kode dalam Diskusi Mahasiswa Teknik Informatika Universitas PGRI Madiun". Jurnalistrendi: Jurnal Linguistik, Sastra, dan Pendidikan 5 (1): 47-55

Hastuti, Dwi. 2020. Alih Kode dan Campur Kode dalam Konten Video Youtube Jang Hansol (Preprint). Surakarta: Universitas Sebelas Maret

Suryani, Ria \& Ian Sopian. 2019. "Alih Kode dan Campur Kode pada Naskah Drama Kabayan Mencari Cinta Karya Salsabila Piriyanti". Parole (Jurnal Pendidikan Bahasa dan Sastra Indonesia) 2 (2): 165-170

Indrayani, Nanik. 2017. "Penggunaan Campur Kode dan Alih Kode dalam Proses Pembelajaran di SMPN Ubung Pulau Buru". Totobuang: Jurnal IImiah Kebahasaan dan Kesastraan 5 (2): 299-314

Indriyani, Yekti. 2019. "Alih Kode dan Campur Kode antara Penjual dan Pembeli di Pasar Prembun Kabupaten Kebumen (Sebuah Kajian Sosiolinguistik)". Bahtera: Jurnal Pendidikan, Bahasa, Sastra, dan Budaya 6 (12): 690-698

Kalangit, Rani Frisia. 2016. Alih Kode dalam Instagram (Suatu Analisis Sosiolinguistik.) (Jurnal Skripsi). Manado: Universitas Sam Ratulangi

Kurniasih, Dwi. \& Sri Aminataz Zuhriyah. 2017. "Alih Kode dan Campur Kode di Pondok Pesantren Mahasiswa Darussalam". Journal Indonesian Language Education and Literature 3 (1): 53-65. doi: http://dx.doi.org/10.24235/ileal.v3il.1521

Laiman, Akhiri, Ngudining Rahayu \& Catur Wulandari. 2018. "Campur Kode dan Alih Kode dalam Percakapan di Lingkup Perpustakaan Universitas Bengkulu". Jurnal IImiah Korpus 2 (1): 45-55 
Liyana, Cut Irna 2017. "Alih Kode dan Campur Kode dalam Komunitas Mahasiswa Perantauan Aceh di Yogyakarta". Community: Pengawas Dinamika Sosial 3 (2): 142154

Mahesa, Nia. 2017. "Alih Kode dan Campur Kode Pemakaian Bahasa Indonesia dalam Interaksi Pembelajaran di Kelas (Penelitian Etnografi Komunikasi di SD Negeri 14 Gurun Laweh Padang)". Bahtera: Jurnal Pendidikan Bahasa dan Sastra 16 (1): 46-56

Meldani, Amalia. 2018. "Alih Kode dan Campur Kode dalam Novel The Sweet Sins Karya Rangga Wirianto Putra". Jurnal Sapala 5 (1): 1-11

Mufrodi. 2015. "Fonologi dan Morfologi Bahasa Arab "Amiyah Mesir". Arabiyat: Jurnal Pendidikan Bahasa Arab dan Kebahasaaraban 2 (2): 192-215

Muharramah, M. 2019. Kedudukan Bahasa Indonesia dan Bahasa Inggris dalam Bidang IImu Pengetahuan di Era Global (Preprint). Surakarta: Universitas Sebelas Maret

Pancarani, Afridesy Puji, Zaqiatul Mardiah \& Ariadna Ayu Miranda. 2016. "Bahasa Amiyah Mesir (Sejarah, Kaidah, dan Perbedaannya dengan Bahasa Arab Klasik". Jurnal Al Azhar Indonesia Seri Humaniora 3 (3): 203-214

Rohmah, Afifah Nur, R Herdiana \& Rina Agustini. 2019. "Alih Kode dan Campur Kode dalam Komunikasi Formal Siswa Kelas XI IPS di SMA Terpadu Ar-Risalah Ciamis". Jurnal IImiah Diksatrasia: Pendidikan Bahasa dan Sastra Indonesia 3 (1): 18-27

Septiani, Dwi. 2020. "Majas dan Citraan dalam Puisi Mishima Karya Goenawan Mohamad (Kajian Stilistika)". Jurnal Sasindo Unpam 8 (1): 12-24

Setiyawan, Agung. 2018. "Problematika Keragaman Latar Belakang Pendidikan Mahasiswa dan Kebijakan Program Pembelajaran Bahasa Arab". Arabiyat: Jurnal Pendidikan Bahasa Arab dan Kebahasaaraban 5 (2): 195-213

Wardani, Khusnul. 2019. Kedudukan Bahasa Indonesia dan Eksistensi Bahasa Inggris dalam Ranah Pendidikan sebagai Upaya Menjawab Tantangan Global (Preprint). Surakarta: Universitas Sebelas Maret

Yusnan, Muhammad, Kamasiah, Risman lye \& Karim, Harziko, Riki Bugis. 2020. "Alih Kode dan Campur Kode pada Novel Badai Matahari Andalusia Karya Hary El-Parsia". Uniqbu Journal of Social Sciences 1 (1): 1-11

\section{ARTICLE CITATION IN THE CHICAGO MANUAL OF STYLE 16}

\section{In-text Citation}

Aziz, Al Farisi, and Muttaqien $(2021,173)$.....

..... (Aziz, Al Farisi, and Muttaqien 2021, 173)

\section{Reference List Entry}

Aziz, Jamaluddin Abdul, Mohamad Zaka Al Farisi, and Muhammad Zainal Muttaqien. 2021. "Code Switching and Code Mixing in the Arabic Learning of Egypt Sandwich Program 2019". Leksema: Jurnal Bahasa dan Sastra 6 (2): 167-179. https://doi.org/10.22515/ ljbs.v6i2.3004.

Copyright @ 2021 Leksema: Jurnal Bahasa dan Sastra 